\title{
Faktor Risiko Hiperkoagulasi pada Thalassemia Anak
}

\author{
Ridha Kurnia Tejasari, Lelani Reniarti, Sjarif Hidajat Effendi \\ Departemen Ilmu Kesehatan Anak Fakultas Kedokteran Universitas Padjadjaran/Rumah Sakit Dr. Hasan \\ Sadikin, Bandung
}

\begin{abstract}
Latar belakang. Hiperkoagulasi merupakan salah satu komplikasi thalassemia yang telah terjadi sebelum manifestasi klinis ditemukan pada thalassemia anak. Sampai saat ini belum pernah ada penelitian khusus mengenai faktor risiko hiperkoagulasi pada thalassemia anak.

Tujuan. Menentukan faktor risiko hiperkoagulasi pada thalassemia anak.

Metode. Desain penelitian potong lintang dilakukan sejak bulan Maret hingga April 2014 terhadap 87 subjek di Poliklinik Thalassemia Anak RSHS Bandung. Hiperkoagulasi diketahui berdasarkan tromboelastografi (TEG), apabila ditemukan minimal 2 dari 4 parameter terpenuhi dengan atau tanpa nilai CI lebih dari 3. Analisis statistik faktor risiko dengan uji chi-square/Fisher dan regresi logistik.

Hasil. Prevalensi hiperkoagulasi thalassemia anak di RSHS Bandung 70\% (61 subjek). Usia termuda hiperkoagulasi positif adalah 5 tahun. Faktor risiko hiperkoagulasi thalassemia anak yang bermakna adalah peningkatan jumlah trombosit ( $p=0,002$; RP1,08; IK95\%:1,003-1,013), sedangkan variabel lainnya tidak berhubungan. Pasien pascasplenektomi sejumlah 9 subjek dengan kadar trombosit $>500.000 \mathrm{~mm}^{3}$. Hiperkoagulasi positif dapat memiliki jumlah trombosit yang meningkat dan/atau gangguan fungsi trombosit berdasarkan TEG.

Kesimpulan. Peningkatan jumlah trombosit merupakan faktor risiko hiperkoagulasi thalassemia anak di RSHS Bandung. Sari Pediatri 2015;16(6):427-33.
\end{abstract}

Kata kunci: anak, faktor risiko, hiperkoagulasi, thalassemia, tromboelastografi (TEG)

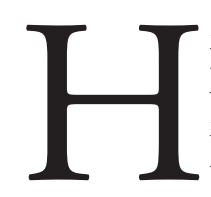

iperkoagulasi merupakan salah satu komplikasi thalassemia. Berbagai penelitian mengemukakan bahwa pada thalassemia anak telah terjadi hiper-

\footnotetext{
Alamat korespondensi:

Dr. Ridha Kurnia Tejasari. Departemen Ilmu Kesehatan Anak Fakultas Kedokteran Universitas Padjadjaran/Rumah Sakit Dr. Hasan Sadikin Jl. Pasteur No.38 Bandung 40163, Indonesia, Telp. (022) 3035957. E-mail: ridha2208@yahoo.com_
}

koagulasi, meskipun manifestasi klinis nyata jarang ditemukan. ${ }^{1-4}$ Selama tahun 2013, Yayasan Thalasemia Indonesia (YTI-POPTI) Jawa Barat mendata 13 pasien thalassemia meninggal mendadak dengan kecurigaan tromboemboli dan 5 di antaranya adalah usia anak. ${ }^{5}$

Hiperkoagulasi thalassemia terjadi primer akibat kelainan genetik ${ }^{6}$ dan sekunder akibat faktor risiko nongenetik (fenotip). ${ }^{7}$ Sampai saat ini belum ada kesepakatan pemeriksaan standar diagnostik hiperkoagulasi pada anak. Alternatif pemeriksaan hiperkoagulasi adalah 
tromboelastografi (TEG) yang dapat mewakili fungsi trombosit, hemostatik, dan fibrinolisis. ${ }^{8}$

Rosendaal ${ }^{9}$ mengemukakan bahwa pertambahan usia meningkatkan risiko trombosis. Pada thalassemia mayor terjadi hemolisis lebih berat dan bergantung pada transfusi darah sehingga semakin bertambah usia dan lama sakit maka terjadi kerusakan endotel vaskular kronik dan peningkatan aktivitas prokoagulan. ${ }^{10}$ Semakin lama thalassemia diderita maka semakin tinggi risiko hiperkoagulasi karena berkaitan kepatuhan transfusi, terapi kelasi besi yang tidak optimal, faktor biaya, anemia rekuren serta cedera endotel kronik yang kontinu. ${ }^{11}$ Semakin berat derajat thalassemia maka semakin berat proses hemolisis sehingga semakin bergantung pada transfusi darah dan meningkatkan risiko penumpukan besi. ${ }^{12,13}$

Tipe thalassemia intermedia yang non-dependent transfusion terjadi hemolitik kronik berkepanjangan, peningkatan aktivitas prokoagulan kronis, dan akumulasi besi akibat peningkatan absorpsi besi intestinal dibandingkan dengan tipe thalassemia mayor. ${ }^{14,15}$ Kadar hemoglobin yang lebih rendah terjadi akibat proses hemolitik yang lebih hebat. ${ }^{16}$ Peningkatan jumlah trombosit memicu pembentukan trombin dan stimulasi aktivitas prokoagulan. ${ }^{7}$ Absennya fungsi lien pada splenektomi meningkatkan jumlah trombosit, meningkatkan aktivitas prokoagulan, agregasi trombosit, dan memperberat status aktivasi trombosit kronik $^{17-20}$ sehingga terdapat hubungan langsung antara splenektomi dengan jumlah trombosit yang meningkat. Proses hemolisis dan peningkatan produksi free iron menyebabkan cedera endotel vaskular kronik akibat toksisitas stres oksidatif. ${ }^{19,21}$

Penelitian hiperkoagulasi thalassemia sebelumnya terbatas pada kelainan primer genetik ${ }^{6}$ dan tipe thalassemia intermedia. ${ }^{15,18,21}$ Tujuan penelitian ini adalah untuk mengetahui faktor risiko usia, lama sakit, derajat dan tipe thalassemia, kadar hemoglobin pretransfusi rata-rata, jumlah trombosit, dan kadar feritin serum yang memengaruhi hiperkoagulasi pada thalassemia anak.

\section{Metode}

Penelitian observasional analitik dengan rancangan potong silang telah dilakukan pada bulan Maret 2014-April 2014. Subjek penelitian adalah anak berusia 5-14 tahun yang berobat di Poli Thalassemia
Anak RSHS Bandung. Kriteria inklusi adalah anak thalassemia usia 5-14 tahun dan memiliki catatan medis lengkap. Kriteria eksklusi adalah pasien dengan riwayat perdarahan, mempunyai penyakit kronik selain thalassemia (keganasan, penyakit jantung bawaan, gagal jantung, hepatitis kronik, gagal ginjal kronik, sindrom nefrotik, epilepsi, dan diabetes melitus), dan riwayat minum obat golongan AINS (ibuprofen pada 1 minggu sebelumnya). Penelitian telah mendapat persetujuan Komite Etik Penelitian Kesehatan Fakultas Kedokteran Universitas Padjadjaran/RSUP Dr. Hasan Sadikin Bandung dan persetujuan keikutsertaan penelitian diadapatkan dari orangtua/wali pasien. Data penelitian diperoleh dari anamnesis, pemeriksaan fisik, dan data rekam medis.

Hiperkoagulasi dinilai dengan TEG, apabila ditemukan minimal 2 dari 4 parameter terpenuhi, yaitu R-time memendek, K-time memendek, sudut $\alpha$ meningkat, besar Minimal Amplitudo (MA) meningkat, dengan atau tanpa nilai $\mathrm{CI}>3 .{ }^{22}$ Derajat thalassemia terdiri atas derajat ringan, sedang, dan berat. ${ }^{12}$ Tipe thalassemia terdiri atas thalassemia mayor dan intermedia. ${ }^{14}$ Penilaian terhadap faktor risiko usia, lama sakit, derajat dan tipe thalassemia, kadar hemoglobin pretransfusi rata-rata, jumlah trombosit, dan kadar feritin serum menggunakan analisis bivariabel dengan uji chi-square dan Fisher. Analisis multivariat dengan uji regresi logistik dengan program SPSS for windows versi 15.0 , nilai $\mathrm{p}<0,05$.

\section{Hasil}

Selama periode Maret hingga April 2014 didapatkan 87 subjek usia 5-14 tahun yang kontrol ke poli thalassemia anak dengan prevalensi hiperkoagulasi $61(70 \%)$ subjek. Median usia adalah 9 tahun dan termuda dengan hiperkoagulasi positif adalah 5 tahun. Sembilan subjek dengan jumlah trombosit $>500.000$ $\mathrm{mm}^{3}$ adalah pasien pascasplenektomi. Karakteristik subjek penelitian tertera pada Tabel 1 .

Gambaran TEG pasien thalassemia anak tertera pada Tabel 2. Hiperkoagulasi positif memiliki $\mathrm{R}$-time atau $\mathrm{K}$-time yang memendek, sudut $\alpha$ atau MA yang meningkat. Berdasarkan analisis bivariabel (Tabel 3) terdapat 2 variabel bebas yang memiliki nilai $\mathrm{p}<0,25$, yaitu lama sakit dan jumlah trombosit, kemudian dilakukan analisis regresi logistik. Faktor risiko hiperkoagulasi yang bermakna adalah 
Tabel 1. Karakteristik pasien thalassemia anak $(\mathrm{n}=87)$

\begin{tabular}{|c|c|}
\hline & Jumlah (\%) \\
\hline \multicolumn{2}{|l|}{ Usia (tahun) } \\
\hline$<10$ & $45(52)$ \\
\hline$\geq 10$ & $42(48)$ \\
\hline \multicolumn{2}{|l|}{ Jenis kelamin } \\
\hline Laki-laki & $51(59)$ \\
\hline Perempuan & $36(41)$ \\
\hline \multicolumn{2}{|l|}{ Lama Sakit (tahun) } \\
\hline$<5$ & $23(26)$ \\
\hline $5-10$ & $37(43)$ \\
\hline$>10$ & $27(31)$ \\
\hline \multicolumn{2}{|l|}{ Derajat thalassemia } \\
\hline Ringan & $3(3)$ \\
\hline Sedang & $51(59)$ \\
\hline Berat & $33(38)$ \\
\hline \multicolumn{2}{|l|}{ Tipe thalassemia } \\
\hline Mayor & $46(53)$ \\
\hline Intermedia & $41(47)$ \\
\hline \multicolumn{2}{|c|}{ Kadar hemoglobin (g/dL) } \\
\hline$<5$ & $3(3)$ \\
\hline $5-9$ & $82(94)$ \\
\hline$>9$ & $2(8)$ \\
\hline \multicolumn{2}{|c|}{ Kadar trombosit $\left(10^{3} \mathrm{~mm}^{3}\right)$} \\
\hline Rerata (SD) & $285,09(163,94)$ \\
\hline Median & 261 \\
\hline Rentang & $56-921$ \\
\hline \multicolumn{2}{|l|}{ Kadar feritin $(\mu \mathrm{g} / \mathrm{L})$} \\
\hline$<1.000$ & $6(7)$ \\
\hline $1.000-2.500$ & $17(20)$ \\
\hline $2.500-5.000$ & $34(39)$ \\
\hline $5.000-10.000$ & $27(31)$ \\
\hline$>10.0000$ & $3(3)$ \\
\hline \multicolumn{2}{|l|}{ Splenektomi } \\
\hline $\mathrm{Ya}$ & $9(10)$ \\
\hline Tidak & $78(90)$ \\
\hline \multicolumn{2}{|l|}{ Hiperkoagulasi } \\
\hline Positif & $61(70)$ \\
\hline Negatif & $26(30)$ \\
\hline \multicolumn{2}{|l|}{ Jenis kelator besi* } \\
\hline Deferipron & $48(60)$ \\
\hline Deferasiroks & $28(35)$ \\
\hline Deferoksamin & $4(5)$ \\
\hline \multicolumn{2}{|l|}{ Terapi kelasi besi* } \\
\hline Optimal & $30(37)$ \\
\hline Tidak optimal & $50(64)$ \\
\hline
\end{tabular}

Keterangan: *total 80 subjek, 7 subjek tanpa terapi kelasi besi

peningkatan jumlah trombosit ( $\mathrm{p}=0,002$; $\mathrm{RP} 1,08$; IK95\%:1,003-1,013), sedangkan variabel lainnya tidak berhubungan bermakna (Tabel 3 dan Tabel 4).

\section{Pembahasan}

Penelitian ini melaporkan penggunaan TEG modern dengan sistem komputerisasi untuk menentukan hiperkoagulasi pada thalassemia anak. Dijumpai 70\% hiperkoagulasi positif, tidak berbeda jauh dengan penelitian Lismayanti ${ }^{3}(65,6 \%)$ hiperkoagulasi positif, tetapi tidak sejalan dengan penelitian Hastuti ${ }^{23}$ hanya $5 \%$ subjek thalassemia dewasa yang mengalami hiperkoagulasi. Penelitian ini menggunakan TEG dengan 4 parameter, yaitu $\mathrm{R}$-time, $\mathrm{K}$-time, sudut alpha $(\alpha)$, dan nilai MA seperti halnya penelitian Subramanian $\mathrm{dkk}^{22}$ yang menyatakan bahwa kriteria hiperkoagulasi ditegakkan apabila terdapat minimal 2 atau lebih dari 4 parameter TEG. Penelitian Lismayanti ${ }^{3}$ menggunakan 2 parameter, yaitu $\mathrm{R}$-time dan $\mathrm{K}$-time, sedangkan penelitian $\mathrm{Hastuti}^{23}$ hanya menggunakan parameter CI saja. Parameter CI tidak dapat dijadikan satu-satunya parameter hiperkoagulasi. ${ }^{24}$ Penelitian systematic review $\mathrm{Dai}^{25}$ menyatakan parameter MA merupakan parameter terbaik untuk memprediksi tromboemboli. Parameter sudut $\alpha$ berkaitan erat dengan fungsi trombosit, sedangkan MA berkaitan dengan fungsi koagulasi, yaitu D-dimer dan fibrinogen. ${ }^{4}$

Penelitian sebelumnya untuk diagnostik hiperkoagulasi thalassemia dilakukan pemeriksaan kadar PT, aPTT, D-dimer, fibrinogen, AT III, protein C, dan protein S. ${ }^{1,2,4,26}$ Sampai saat ini belum ada kesepakatan standar baku pemeriksaan hiperkoagulasi terutama pada anak.

Alat TEG merupakan alternatif pilihan alat yang praktis, cepat, memerlukan sampel sedikit, tersedia, relatif murah, dengan sensitivitas $0 \%-100 \%$ dan spesifisitas 62\%-92\%. Disamping itu, TEG mampu menggambarkan hiperkoagulasi, berupa fungsi koagulasi, trombosit, dan fibrinolisis secara global dan menyeluruh, ${ }^{25,27}$ bahkan TEG direkomendasikan sebagai skrining hiperkoagulasi. ${ }^{28}$

Hasil penelitian menunjukkan bahwa peningkatan jumlah trombosit semakin meningkatkan risiko hiperkoagulasi. Hal tersebut sejalan dengan penelitian Canatan dan Zorlu ${ }^{29}$ serta $\mathrm{Abbas}^{30}$ bahwa peningkatan jumlah trombosit meningkatkan pembentukan trombin dan stimulasi aktivitas prokoagulan. ${ }^{31}$ Abnormalitas eritrosit pada thalassemia menyebabkan fosfatidilserin berada di sisi luar membran eritrosit dan menyebabkan peningkatan aktivitas dan adhesi trombosit sehingga risiko hiperkoagulasi meningkat. 
Ridha Kurnia Tejasari dkk: Faktor risiko hiperkoagulasi pada thalassemia anak

Tabel 2. Gambaran TEG pada pasien thalassemia anak

\begin{tabular}{|c|c|c|c|}
\hline \multirow[b]{2}{*}{ TEG } & \multicolumn{2}{|c|}{ Hiperkoagulasi } & \multirow[b]{2}{*}{ Nilai normal } \\
\hline & $\begin{array}{l}\text { Positif } \\
\mathrm{n}=61\end{array}$ & $\begin{array}{c}\text { Negatif } \\
n=26\end{array}$ & \\
\hline \multicolumn{4}{|l|}{ R-time (menit) } \\
\hline Rerata (SD) & $7,2(1,6)$ & $10,3(2,6)$ & \\
\hline Median & 7,1 & 9,6 & $9-27$ \\
\hline Rentang & $4,0-12,6$ & $7,1-19,7$ & \\
\hline \multicolumn{4}{|l|}{ K-time (menit) } \\
\hline Rerata (SD) & $1,7(0,4)$ & $2,9(0.8)$ & \\
\hline Median & 1,7 & 2,8 & $2-9$ \\
\hline Rentang & $0,8-2.2$ & $1,9-5,8$ & \\
\hline \multicolumn{4}{|l|}{ Sudut $\alpha$ (derajat) } \\
\hline Rerata $(\mathrm{SD})$ & $66,2(4,7)$ & $53,2(5,6)$ & \\
\hline Median & 65.5 & 53,8 & $22-58$ \\
\hline Rentang & $58,8-77,8$ & $41,2-62,7$ & \\
\hline \multicolumn{4}{|l|}{$\mathrm{MA}(\mathrm{mm})$} \\
\hline Rerata (SD) & $65,3(4,9)$ & $58,5(4,6)$ & \\
\hline Median & 64,6 & 59,7 & $44-64$ \\
\hline Rentang & $52,1-77,4$ & $48,8-70,0$ & \\
\hline \multicolumn{4}{|l|}{$\mathrm{CI}$} \\
\hline Rerata (SD) & $2,4(0,8)$ & $1,0(0,5)$ & \\
\hline Median & 2,4 & 0,9 & $-3-+3$ \\
\hline Rentang & $0,1-4,3$ & $0,2-2,2$ & \\
\hline
\end{tabular}

Hal tersebut diketahui dari peningkatan metabolit prostasiklin $\left(\mathrm{PGI}_{2}\right)$ dan tromboksan A2 $\left(\mathrm{TXA}_{2}\right) .{ }^{19}$ Sembilan anak dengan jumlah trombosit $>500.000 /$ $\mathrm{mm}^{3}$ adalah pascasplenektomi sehingga memiliki risiko hiperkoagulasi dan trombosis yang lebih tinggi. Absennya fungsi lien pada splenektomi akan meningkatkan aktivitas prokoagulan, agregasi trombosit, dan memperberat status aktivasi trombosit kronik. ${ }^{17,18}$ Kelebihan penelitian kami adalah pasien hiperkoagulasi positif dapat memiliki jumlah trombosit meningkat dan/atau gangguan fungsi trombosit berdasarkan gambaran TEG. Hiperkoagulasi positif ditemukan pada kasus dengan jumlah trombosit normal, nonsplenektomi, tetapi gambaran TEG menyokong hiperkoagulasi. Beberapa subjek ditemukan trombositopenia, hal ini akibat hipersplenism, sehingga terjadi sekuestrasi di dalam lien yang menyebabkan trombosit yang bersirkulasi di dalam aliran darah menjadi berkurang. ${ }^{32}$ Perlu analisis lebih lanjut apakah terdapat gejala klinis, meskipun ringan, terkait hiperkoagulasi seperti keluhan nyeri kepala, pegalpegal, dan parestesi pada ekstremitas. ${ }^{31,33}$
Faktor usia bukan merupakan faktor risiko hiperkoagulasi. Penelitian sebelumnya menyatakan bahwa usia anak dini pun telah terjadi hiperkoagulasi, ${ }^{1-3}$ tetapi tidak menggunakan analisis multivariat. Berbeda dengan teori yang dikemukakan Rosendaal ${ }^{9}$ bahwa pertambahan usia meningkatkan risiko trombosis. Dengan tata laksana thalassemia yang semakin berkembang, usia harapan hidup semakin tinggi maka semakin bertambah usia dan lama sakit kecenderungan thalassemia menjadi progresif dengan berbagai risiko komplikasi. Terutama di negara berkembang, akibat kepatuhan transfusi, terapi kelasi besi tidak optimal, dan faktor biaya kejadian komplikasi semakin tinggi. ${ }^{34,35}$ Penelitian kami mempertimbangkan homogenitas subjek karena usia splenektomi minimal adalah 5 tahun.

Faktor lama sakit, derajat, dan tipe thalassemia bukan merupakan faktor risiko hiperkoagulasi. Tampaknya terdapat faktor risiko lain yang berperan dan perlu diteliti lebih lanjut, seperti faktor genetik, usia saat diagnostik thalassemia, ${ }^{36}$ maupun jumlah sampel yang lebih besar. Patofisiologi iron overload yang 
Tabel 3. Analisis bivariabel faktor risiko hiperkoagulasi thalassemia anak

\begin{tabular}{|c|c|c|c|c|c|}
\hline \multirow[b]{2}{*}{ Faktor Risiko } & \multicolumn{2}{|c|}{ Hiperkoagulasi } & \multirow[b]{2}{*}{ Nilai $p^{*}$} & \multirow[b]{2}{*}{$\mathrm{RP}^{\#}$} & \multirow[b]{2}{*}{ IK95\%\# } \\
\hline & $\begin{array}{c}\mathrm{Ya} \\
\mathrm{n}=61\end{array}$ & $\begin{array}{l}\text { Tidak } \\
\mathrm{n}=26\end{array}$ & & & \\
\hline Usia (tahun) & & & 0,834 & & \\
\hline$<10$ & $32(71)$ & $13(29)$ & & 1,00 & \\
\hline$\geq 10$ & $29(69)$ & $13(31)$ & & 1,10 & $0,44-2,76$ \\
\hline Lama sakit (tahun) & & & 0,147 & & \\
\hline$<5$ & $17(74)$ & $6(26)$ & & 1,00 & \\
\hline $5-10$ & $22(60)$ & $15(40)$ & & 0,80 & $0,56-1,15$ \\
\hline$>10$ & $22(82)$ & $5(18)$ & & 1,10 & $0,81-1,49$ \\
\hline Derajat thalassemia & & & 0,840 & & \\
\hline Ringan & $2(67)$ & $1(33)$ & & 1,00 & \\
\hline Sedang & $37(72)$ & $14(28)$ & & 1,09 & $0,48-2,47$ \\
\hline Berat & $22(67)$ & $11(33)$ & & 1,00 & $0,43-2,31$ \\
\hline Tipe thalassemia & & & 0,906 & & \\
\hline Mayor & $32(70)$ & $14(30)$ & & 0,98 & $0,75-1,29$ \\
\hline Intermedia & $29(71)$ & $12(29)$ & & & \\
\hline Kadar Hb (g/dL) & & & 0,432 & & \\
\hline$<5$ & $3(100)$ & $0(0)$ & & 2,00 & $0,50-8,0$ \\
\hline $5-9$ & $57(69)$ & $25(31)$ & & 1,39 & $0,35-5,60$ \\
\hline$>9$ & $1(50)$ & $1(50)$ & & 1,0 & \\
\hline Rerata (SD) & $7,3(1,1)$ & $7,5(0,9)$ & & & \\
\hline Rentang & $4,0-9,3$ & $5,6-9,1$ & & & \\
\hline$\sum$ Trombosit $\left(10^{3} \mathrm{~mm}^{3}\right)$ & 61 & 26 & $<0,001$ & & \\
\hline Rerata (SD) & $321,85(170,12)$ & $198,85(109,36)$ & & & \\
\hline Median & 287 & 155,5 & & & \\
\hline Rentang & $103-921$ & $56-420$ & & & \\
\hline Kadar feritin $(\mu \mathrm{g} / \mathrm{L})$ & & & 0,901 & & \\
\hline$<1000$ & $4(67)$ & $2(33)$ & & 1,0 & \\
\hline $1000-2500$ & $13(70)$ & $4(24)$ & & 1,15 & $0,61-2,14$ \\
\hline $2500-5000$ & $22(65)$ & $12(35)$ & & 0,97 & $0,52-1,80$ \\
\hline $5000-10.000$ & $20(74)$ & $7(26)$ & & 1,11 & $0,60-2,04$ \\
\hline$>10.000$ & $2(67)$ & $1(33)$ & & 1.0 & $0,38-2,66$ \\
\hline Mean (SD) & $4327,7(2671,9)$ & $3967,8(2273,3)$ & & & \\
\hline Rentang & $518-10.835$ & $490-11.877$ & & & \\
\hline
\end{tabular}

Keterangan: ${ }^{*}$ p tingkat kemaknaan berdasarkan uji chi-kuadrat atau Uji Fisher

${ }^{*}$ Rasio prevalensi (RP), interval kepercayaan 95\% (IK95\%)

Tabel 4. Analisis multivariat faktor risiko hiperkoagulasi dengan regresi logistik

\begin{tabular}{lcccc}
\hline Variabel & Koefisien B & Standar Eror (B) & Nilai p & Rasio prevalensi (IK 95\%) \\
\hline$\sum{\text { trombosit }\left(10^{3} \mathrm{~mm}^{3}\right)}^{0,008}$ & 0,003 & $0,002^{*}$ & $1,08(1,003-1,013)$ \\
\hline Keterangan: $^{*} \mathrm{p}<0,05$ & & &
\end{tabular}

berperan dalam hiperkoagulasi thalassemia intermedia dan thalassemia mayor sangat berbeda dan penentuan tipe thalassemia tidak mudah-terkait variasi genetik dan variasi gejala klinis yang luas. Penelitian Taher dan Ismaa' el ${ }^{15}$ serta Borgna Pignatti ${ }^{33}$ mengemukakan bahwa thalassemia intermedia memiliki risiko tromboemboli lebih tinggi dibandingkan dengan thalassemia mayor.

Kadar hemoglobin dan kadar feritin bukan merupakan faktor risiko. Hal tersebut berbeda dengan 
penelitian Taher $\mathrm{dkk}^{21}$ yang melaporkan kadar $\mathrm{Hb}<9$ $\mathrm{g} / \mathrm{dL}$ meningkatkan risiko trombosis pada populasi TI. Jumlah subjek dengan kadar $\mathrm{Hb}<5$ dan $>9 \mathrm{~g} / \mathrm{dL}$ pada penelitian ini juga sedikit. Kadar $\mathrm{Hb}$ yang lebih rendah akan meningkatkan risiko hiperkoagulasi. Proses hemolisis dan peningkatan produksi free iron menyebabkan cedera endotel vaskular kronik akibat toksisitas stres oksidatif. ${ }^{19,21}$ Penelitian Taher pada populasi TI mengemukakan bahwa kadar feritin $>1.000 \mu \mathrm{g} / \mathrm{L}$ meningkatkan risiko trombosis. Berbeda dengan penelitian ini, kadar feritin serum tidak berhubungan bermakna terhadap hiperkoagulasi. Selain itu, pada kadar feritin $<1.000 \mu \mathrm{g} / \mathrm{L}$ sudah terjadi hiperkoagulasi. Sampai saat ini belum ada penelitian pada kadar feritin berapa sudah terjadi hiperkoagulasi. Hal tersebut memerlukan penelitian lanjutan. Pemeriksaan kadar non transferrin bound iron (NTBI) dan saturasi transferin penting dilakukan sebagai penanda iron overload.

\section{Kesimpulan}

Penelitian ini adalah peningkatan jumlah trombosit merupakan faktor risiko hiperkoagulasi pada thalassemia anak.

\section{Daftar pustaka}

1. Eldor A, Durst R, Hy-Am E. A chronic hypercoagulable state in patients with beta-thalassemia major is already present in childhood. Br J Haematol 1999; 107:739-46.

2. Kemahli S, Gurman C, Egin Y. Hypercoagulability in Children with Thalassemia Major. Clin Appl Thrombosis 1997;3:129-32.

3. Lismayanti L. Prevalensi hiperkoagulabilitas dan gambaran serta hubungan antara hasil pemeriksaan tromboelastografi dengan D-dimer pada anak yang menderita thalassemia mayor di perjan RS Hasan Sadikin Bandung (Tesis). Bandung: Fakultas Kedokteran Universitas Padjadjaran, 2003.

4. Yee DL, Edwards RM. Thromboelastographic and hemostatic characteristic in pediatric patients with sickle cell disease. Arch Pathol Lab Med 2005;129:760-5.

5. Yayasan Thalassemia Indonesia cabang Jawa Barat. RS Dr. Hasan Sadikin Bandung. 2014.

6. Iolascon A, Giordano P, Storelli S. Thrombophilia in thalassemia major patients: analysis of genetic predisposing factors. Haematologica 2001;86:1112-3.

7. Cappellini MD, Motta I, Musallam KM, Taher AT. Redefining thalassemia as a hypercoagulable state. Ann N Y Acad Sci 2010;1202:231-6.

8. Narani K. Thromboelastography in the perioperative periode. Indian J Anesth 2005;49:89-95.

9. Rosendaal RF. Venous thrombosis: the role of genes, environment, and behavior. Hematology Am Soc Hematol Educ Program 2005;1:1-12.

10. Lazarchick J, Oswald M. Interaction of fibrinolysis, coagulation, and kinin system: Disseminated intravascular coagulation and related pathology. Dalam: Harmening DM, penyunting. Clinical hematology and fundamentals of hemostasis. Edisi ke-5. Philadelphia: Davis company;2008.h.643-59.

11. Kuypers FA. The role of phosphatidylserine in recognition and removal of erythrocytes. Cell Mol Biol 2004;50:147-58.

12. Sripichai O, Whitecre J, Munkongdee T. Genetic analysis of candidate modifier polymorphisms in $\mathrm{Hb}$ E- $\beta 0$-talasemia patients. Ann NY Acad Sci 2005; 1054:433-8.

13. Cappellini MD, Mussalam K, Marcon A. Coagulopathy in beta thalassemia: current understanding and future perspective. Medit J Hem Infect Dis 2009;1:1-6.

14. Nadkarni A, Gorakshakar A, Colah R. Evaluation of the clinical severity of beta-thalassemia homozygous patients using a phenotypic scoring system. J Chinese Clin Med 2007;21:439-47.

15. Taher A, Isma'eel H. Prevalence of thromboembolic events among 8860 patients with thalassemia major and intermedia in the Mediterranean area and Iran. Thromb Haemost 2006;96:488-91.

16. Singer ST, Ataga KI. Hyoercoagulability in sickle cell disease and beta-thalassemia Curr Molecular Med 2008;8:639-45.

17. Cappellini MD, Grespi E. Coagulation and splenectomy: an overview. Ann N Y Acad Sci 2005;1054:317-24.

18. Taher AT, Musallam KM. Splenectomy and thrombosis: the case of thalassemia intermedia. J Thromb Haemost 2010;8:2152-8.

19. Taher AT, Otrock ZK, Uthman I, Cappellini MD. Thalassemia and hypercoagulability.Blood Rev 2008; 22:283-92.

20. Thalassemia International Federation (TIF). Blood transfusion therapy in beta-thalassemia mayor. Dalam: Cappellini MD. Guidelines for the clinical management of thalassemia. Edisi ke-2 revisi. Cyprus: Thalassemia 
International Federation;2008.h. 20-32.

21. Taher AT, Musallam KM, Karimi M. Overview on practices in thalassemia intermedia management aiming for lowering complication rates across a region of endemicity: the OPTIMAL CARE study. Blood 2010;115:1886-92.

22. Subramanian A, Albert V, Agrawal D. Evaluation of the utility of thromboelastography in a tertiary trauma care centre. Diakses pada 3 Juni 2015. Didapat dari:http:// www.ncbi.nlm.nih.gov/pmclarticles/PMC3947774/

23. Hastuti TS. Hubungan volume darah transfusi dengan koagulabilitas pada penderita thalassemia yang mendapat transfusi berkala dan belum menjalani splenektomi (Tesis). Bandung: Fakultas Kedokteran Universitas Padjadjaran, 2011.

24. Lee BY, Butler G, Al-Waili N. Role of thrombelastograph haemostasis analyser in detection of hypercoagulability following surgery with and without use of intermittent pneumatic compression. J Med Eng Technol 2010; 34:166-71.

25. Dai Y, Lee A, Critchley AL. Does thromboelastography predict postoperative thromboembolic events? A systematic review of the literature. Anesth Analg. 2009;108:734-42.

26. NHS Foundation Trust. Guidelines for thrombophila testing. Harrogate and District; 2010. hlm. 1-12. Diunduh 11 November 2013. Didapat dari: www.nhs.co.id

27. American association of clinical chemistry. 2011. Diunduh 18 Februari 2014. Didapat dari: www.aacc.com

28. O'Donnell J, Riddell A, Owners D. Role of the thromboelastograph as an adjunctive test in thrombophilia screening. Blood Coagul Fibrinolysis 2004;15:207-11.

29. Canatan D, Zorlu M. Thrombosis after splenectomy in patients with thalassemia. Turk J Haematol 2001; 18:259-63.

30. Abbas SS. Thromboembolic events in beta-thalassemia major patients. J Fac Med Baghdad 2006;28:370-3.

31. Cappelini MD. Poggiali E TA, Musallam KM. Hypercoagulability in beta-thalassemia: a status quo. Expert Rev. Hematol 2012;5:505-12.

32. Weitz JI. Hemostasis and thrombosis. Dalam: Hoffman R, Benz EJ, Silberstein LE, penyunting. Hematology Basic Principles and Practice. Edisi ke-6. Oklahoma: Churchill Livingstone;2012.h.368-445.

33. Borgna-Pignatti C, Rugolotto S, Stefano PD. Survival and complications in patients with thalassemia major treated with transfusion and deferoxamine. Haematologica 2004;89:1187-93.

34. Thalassemia.Diunduh 13 Februari 2014. Didapat dari: www.thalassemia.com.

35. Kontoghiorghes GJ. The proceedings of the 17th International Conference on Chelation: application of effective chelation therapies in iron loading and non iron loading conditions, and the gap in the prevention and treatment policies on thalassemia between developed and developing countries. Hemoglobin 2009;33:283-6.

36. Ataga KI, Cappellini MD, Rachmilewitz EA. Betathalassemia and sickle cell disease as paradigms of hypercoagulability. Br J Haematol 2007;139:3-13. 